\title{
PEMBINAAN WILAYAH PESISIR DAN PULAU-PULAU TERDEPAN DI INDONESIA DALAM RANGKA MENEGAKKAN KEDAULATAN NASIONAL
}

\section{THE DEVELOPMENT OF COASTAL AREAS AND THE FRONT ISLANDS IN INDONESIA TO ENFORCE NATIONAL SOVEREIGNTY}

\author{
Boy Anugerah \\ Majelis Permusyawaratan Rakyat Republik Indonesia (MPR RI) \\ Jl. Gatot Subroto No.6, RT.1/RW.3, Gelora, Kecamatan Tanah Abang, Kota Jakarta Pusat, Daerah \\ Khusus Ibukota Jakarta 15810, Indonesia. \\ boy.anugerahsip@gmail.com
}

Diserahkan: 10/09/2021 Diperbaiki: 21/10/2021 Disetujui: 11/10/2021

DOI: $10.47441 / \mathrm{jkp} . v 16 \mathrm{i} 2.211$ to this article

\begin{abstract}
Abstrak
Wilayah pesisir dan pulau-pulau terdepan memiliki nilai strategis bagi Indonesia sebagai sebuah negara maritim. Hal ini tidak terlepas dari kekayaan sumber daya alam yang dimiliki oleh kedua entitas maritim tersebut. Namun demikian, nilai strategis tersebut belum dimanfaatkan secara optimal karena wilayah pesisir dan pulau-pulau terdepan belum diberdayakan, baik dalam konteks sosial-perekonomian maupun pertahanan-keamanan. Padahal, secara umum wilayah pesisir dan pulau-pulau terdepan yang diberdayakan secara optimal akan memiliki signifikansi penting dalam menopang kedaulatan nasional. Penelitian ini bertujuan untuk menganalisis permasalahan dan merumuskan solusi terkait pola pembinaan wilayah pesisir dan pulau-pulau terdepan dalam mendukung tegaknya kedaulatan nasional melalui pendekatan tinjauan pustaka. Pengumpulan data dilakukan melalui metode desk research. Analisis data dilakukan dengan metode annotated bibliography. Hasil dari penelitian ini adalah dibutuhkannya mekanisme pembinaan wilayah secara efektif berbasis pengamanan dan pengelolaan. Pengamanan wilayah dapat dilakukan dengan melibatkan masyarakat di wilayah pesisir dan dan pulau-pulau terdepan dalam sistem pertahanan negara melalui skema komponen cadangan, sedangkan pengelolaan wilayah dilakukan dengan lebih mengoptimalkan peran dan kontribusi dari tiga pemangku kepentingan utama, yakni pemerintah, masyarakat, serta kelompok kepentingan lainnya. Kesimpulan dari penelitian ini adalah dalam rangka menegakkan kedaulatan nasional, pembinaan wilayah pesisir dan pulau-pulau terdepan harus dilakukan secara terpadu dan komprehensif dengan berbasis pada pendekatan keamanan dan kesejahteraan. Pendekatan keamanan dapat dimanifestasikan melalui mekanisme pengamanan wilayah secara efektif, sedangkan pendekatan kesejahteraan dapat diwujudkan melalui mekanisme pengelolaan wilayah secara efektif.
\end{abstract}

Kata Kunci: Pembinaan, Wilayah Pesisir, Pulau Terdepan, Kedaulatan Nasional

\begin{abstract}
The coastal areas and the front islands have strategic roles for Indonesia as an archipelagic state. This circumstance is a result of the natural resources contained by the two maritime entities. However, those strategic roles could not be empowered optimally yet, both in terms of socio-economic and security-defense aspects. Whereas, the optimal empowered areas have significance to strengthen the national sovereignty. This research aims to analyze the problems and present the solutions in developing the coastal areas and the front islands to enforce national sovereignty. This research uses a literature review approach. Desk research and annotated bibliography are used as the data collection and analysis methods. The result of this research is that it is important to conduct effective regional development mechanisms
\end{abstract}


based on regional security and management approaches. Effective regional security could be done by involving the community in the state defense system through a reserve component scheme, while effective regional management could be done by enhancing the roles of the three main stakeholders, who are the government, society, and other interest groups (private sector, NGOs, local governments). The conclusion of this research is in terms of enforcing the national sovereignty, the development of the coastal areas and the front islands has to be done comprehensively by combining security and prosperity approaches, which are implemented through effective regional security and management mechanisms.

Keywords: Development, Coastal Areas, Front Islands, National Sovereignty

\section{PENDAHULUAN}

Indonesia adalah negara kepulauan (archipelagic state) terbesar di dunia yang terdiri atas 17.504 pulau dengan luas sekitar 8,4 juta $\mathrm{km}^{2}$ dan memiliki luas perairan sekitar 6,4 juta $\mathrm{km}^{2}$. Luas perairan tersebut terdiri atas luas perairan kepulauan Indonesia 3,11 juta $\mathrm{km}^{2}$, laut teritorial sebesar 0,29 juta $\mathrm{km}^{2}$, luas Zona Ekonomi Eksklusif (ZEE) sebesar 3 juta $\mathrm{km}^{2}$, serta garis pantainya sepanjang $108.000 \mathrm{~km}$ (Mabes TNI AL 2018). Wilayah Indonesia sebagian besar terdiri dari lautan berdasarkan Deklarasi Djuanda pada tanggal 13 Desember 1957. Deklarasi tersebut yang akhirnya mengantarkan Indonesia menjadi sebuah negara kepulauan yang juga telah diakui dunia internasional melalui the United Nation Convention on the Law of the Sea 1982 atau UNCLOS 1982 (Aryani 2021).

Secara geografis, Indonesia memiliki perbatasan maritim dengan sepuluh negara, yaitu Australia, Timor Leste, Singapura, Papua New Guinea, Palau, Filipina, India, Thailand, Malaysia, dan Vietnam (Pushidrosal TNI AL 2018). Indonesia juga memiliki wilayah pesisir dan pulau-pulau terdepan yang berbatasan langsung dengan negara lain. Keberadaan wilayah pesisir dan pulau-pulau terdepan tersebut harus dapat berdaya guna bagi tercapainya kepentingan nasional, khususnya pertahanan negara, dalam rangka memperkokoh kedaulatan nasional. Efektivitas pengamanan wilayah pesisir Indonesia dengan luas laut Indonesia yang meliputi 70 persen dari luas wilayah negara, serta memiliki 17.504 pulau dengan garis pantai terpanjang kedua di dunia, selain merefleksikan betapa luas wilayah laut Indonesia, juga merefleksikan betapa beratnya tanggung jawab pengamanan wilayah pesisir dan pulau-pulau terdepan wilayah Indonesia.

Posisi Indonesia yang terkoneksi dengan arus-arus laut dunia yang disebut Great Ocean Conveyor Belt dan berada di antara Samudera Hindia dan Samudera Pasifik, telah menjadikan lautnya sebagai pusat kepentingan global dalam hal perairan internasional, iklim global, dan keanekaragaman hayati yang identik dengan kekayaan sumber daya yang terkandung di dalamnya (Kuswardani 2020). Dihadapkan pada panjangnya garis pantai yang merefleksikan luasnya wilayah pesisir dan banyaknya pulau menuntut efektivitas pengelolaannya. Sebagaimana dijelaskan di dalam Peraturan Presiden No. 78 Tahun 2005 tentang Pengelolaan Pulau-Pulau Kecil Terluar bahwa dalam rangka menjaga keutuhan wilayah negara, serta meningkatkan kesejahteraan masyarakat di wilayah perbatasan, perlu dilakukan pengelolaan pulau-pulau terdepan dengan memperhatikan keterpaduan pembangunan di bidang sosial, ekonomi, budaya, hukum, sumber daya manusia, serta pertahanan dan keamanan.

Melihat situasi dan kondisi dewasa ini, wilayah pesisir dan pulau-pulau terdepan belum diberdayakan secara optimal dan efektif. Berbagai kejahatan transnasional seperti perompakan atau pembajakan kapal, penangkapan ikan secara ilegal, penyelundupan manusia, perdagangan narkotika dan obat-obat terlarang, serta terorisme, masih sering terjadi dan memanfaatkan celah pengamanan di wilayah pesisir dan pulau-pulau terdepan tersebut. Realitas empirik lainnya adalah seringnya terjadi pelanggaran kedaulatan nasional oleh pihak-pihak asing, seperti kapal-kapal nelayan dan coast guard Cina di Laut Natuna Utara yang merupakan salah satu pulau terdepan di Indonesia. Pada masa lalu, tepatnya 
pada 2002, Indonesia sempat kehilangan Pulau Sipadan dan Ligitan yang notabene masuk kategori pulau-pulau terdepan yang diklaim dan akhirnya jatuh ke tangan Malaysia melalui ketetapan International Court of Justice (ICJ) (Juwana 2013).

Aspek pengelolaan wilayah dan masyarakat juga masih sangat lemah. Data Kementerian Kelautan dan Perikanan Republik Indonesia (KKP RI) menunjukkan bahwa jumlah kemiskinan di daerah pesisir mencapai 32,14 persen dari total jumlah penduduk miskin nasional (Sabarisman 2017). Sedangkan data Kementerian Perhubungan Republik Indonesia (Kemenhub RI) pada 2020 menyebutkan bahwa mayoritas masyarakat pesisir dan pulau-pulau terdepan gagap teknologi yang ditunjukkan dengan minimnya kapasitas kapal-kapal yang digunakan untuk menangkap ikan (di bawah GT 7) dan masih banyak nelayan yang tidak memiliki Pas Kecil. Pas Kecil adalah dokumen penting sebagai tanda kelayakan kapal untuk berlayar. Akibatnya, pemanfaatan sumber daya maritim menjadi tidak optimal dalam mendukung kesejahteraan mereka.

Merujuk pada situasi dan kondisi tersebut, dapat dikatakan bahwa pemberdayaan wilayah pesisir dan pulau-pulau terdepan belum dilakukan secara optimal dan komprehensif, terutama dalam konteks mendukung upaya penegakan kedaulatan nasional. Oleh sebab itu, perlu dirumuskan mekanisme pembinaan wilayah secara efektif sebagai solusi atas permasalahan yang ada dengan berbasis pada pendekatan keamanan (pengamanan wilayah) dan pendekatan kesejahteraan (pengelolaan wilayah). Penelitian ini bertujuan untuk memberikan deskripsi secara mendetil dan mendalam mengenai mekanisme pembinaan wilayah pesisir dan pulau-pulau terdepan dalam rangka memperkokoh kedaulatan nasional Indonesia. Dalam melaksanakan penelitian ini, penulis berpedoman pada hasil riset-riset terdahulu yang memiliki kesamaan objek penelitian, seperti riset yang dilakukan oleh Sekretariat Jenderal DPR RI oleh Dr. Poltak Partogi Nainggolan dan kawan-kawan berjudul "Wilayah Pesisir dan Pulau-Pulau Kecil di Indonesia", serta riset yang dilakukan oleh Badan Pembinaan Hukum Nasional Kemenkumham RI pada 2015 terkait problematika pengelolaan wilayah pesisir dan pulaupulau terdepan, seperti isu degradasi biofisik, isu pemanfaatan dan kewenangan, serta ketidakpastian hukum penguasaan sumber daya. Secara garis besar, kedua penelitian terdahulu tersebut memiliki dua kesamaan dengan penelitian yang penulis lakukan saat ini. Kesamaan pertama adalah menyangkut objek penelitian, yakni wilayah pesisir dan pulaupulau terdepan. Kesamaan kedua adalah upaya-upaya untuk memetakan persoalan serta merumuskan solusi untuk memberdayakan wilayah pesisir dan pulau-pulau terdepan tersebut. Yang menjadi perbedaan dengan penelitian yang penulis lakukan adalah objektif dari penelitian yang dilakukan. Penelitian yang penulis lakukan saat ini terfokus pada upaya-upaya peningkatan pembinaan wilayah pesisir dan pulau-pulau terdepan guna mendukung tegaknya kedaulatan nasional Indonesia. Inilah salah satu unsur kebaruan (novelty) dalam penulisan artikel hasil penelitian ini.

\section{METODE PENELITIAN}

Metode yang digunakan dalam penelitian ini adalah tinjauan pustaka (literature review). Proses pengumpulan data dilakukan dengan desk research melalui pengumpulan data sekunder dari sumber yang relevan dengan objek penelitian. Proses analisis data dilakukan melalui annotated bibliography, yakni pemilahan dan pemilihan data-data yang akan digunakan sebagai rujukan dari sumber-sumber sekunder yang digunakan. Untuk menguji validitas dan reliabilitas data yang dikumpulkan, penulis melakukan proses triangulasi. Penelitian ini menggunakan pendekatan pembinaan, pemberdayaan, efektivitas, dan manajemen organisasi, untuk memahami dan menganalisis secara mendalam variabel-variabel yang menjadi objek penelitian dengan analisis multidisplin ilmu sesuai dengan tinjauan pustaka yang digunakan. 


\section{HASIL DAN PEMBAHASAN}

\section{Mewujudkan Efektivitas Pengamanan Wilayah Pesisir dan Pulau-pulau Terdepan}

Berdasarkan UU No. 1 Tahun 2014 tentang Perubahan Atas UU No. 27 Tahun 2007 tentang Pengelolaan Wilayah Pesisir dan Pulau-pulau Kecil, definisi wilayah pesisir adalah daerah peralihan antara ekosistem darat dan laut, sedangkan pulau-pulau kecil adalah pulau dengan luas wilayah kurang atau sama dengan $2000 \mathrm{~km}^{2}$ beserta kesatuan ekosistemnya (Agustin Rina Herawati 2019). Definisi tersebut bukan sekedar nomenklatur saja yang dimaktubkan dalam sebuah regulasi. Definisi yang diberikan oleh pemerintah tersebut harus dilihat secara lebih mendalam pemaknaannya. Wilayah pesisir yang merupakan irisan antara wilayah daratan dan perairan merupakan daerah yang sangat dimungkinkan menjadi tempat hidup, lokasi bermukim, dan daerah mata pencaharian penduduk. Ada aspek yang lebih dari sekedar geografi pada definisi tersebut. Definisi wilayah pesisir juga terhubung dengan aspek lainnya, seperti demografi, sosial budaya, dan ekonomi yang melekat pada definisi wilayah pesisir tersebut. Demikian halnya juga dengan pulau-pulau kecil, terlebih lagi dilekatkan frasa "terdepan" pada entitas maritim tersebut. Makna yang tersirat dari definisi tersebut adalah sekecil apapun sebuah wilayah dan kesatuan ekosistem yang melekat, tetap merupakan bagian yang inheren dari NKRI yang harus dijaga kedaulatannya. Aspek terkait bukan hanya persoalan geografi saja, tapi sudah menyangkut aspek pertahanan dan keamanan negara, yang mana kedaulatan dan keutuhan wilayah merupakan harga mati yang harus dijaga oleh pemerintah Indonesia. Pada tataran yuridis, pencantuman definisi kedua entitas maritim tersebut dalam sebuah regulasi yang mengikat dimaksudkan sebagai bentuk pengakuan dan perlindungan yang dilakukan oleh pemerintah agar setiap jengkal wilayah kesatuan memiliki kedudukan hukum yang jelas. Pada tataran internasional, kerangka yuridis nasional tersebut dimaksudkan sebagai dasar hukum resmi yang selaras dengan regulasi internasional agar setiap negara di dunia menghormati kedaulatan nasional dengan tidak melakukan pelanggaran kedaulatan terhadap wilayah yang diatur dalam regulasi tersebut.

Wilayah pesisir dan pulau-pulau terdepan merupakan zona yang memiliki kerentanan tinggi untuk dilanggar oleh pihak-pihak asing yang berkepentingan untuk menguasai sumber daya. Pihak-pihak asing tersebut dapat berupa aktor negara, juga aktor non-negara, seperti perompak, teroris, penyelundup narkoba, pelaku penangkapan ikan secara ilegal, dan sebagainya, yang bergerak secara transnasional (Anugerah 2021). Banyak bukti empirik untuk menjelaskan fenomena ini. Pada bagian ini, akan dijelaskan bukti empirik tersebut secara historis dan kontemporer untuk menekankan sebuah pandangan bahwa ancaman terhadap kedaulatan wilayah adalah hal yang sangat nyata dan perlu diatensi melalui kebijakan yang lebih komprehensif ke depan. Pertama adalah tinjauan dari sisi historis dengan melihat kembali kasus lepasnya Pulau Sipadan dan Pulau Ligitan dari Indonesia. Kasus ini merupakan cermin bahwa pengamanan wilayah kedaulatan adalah harga mutlak yang tidak bisa ditawar-tawar lagi. Permasalahan kedaulatan bukan sekedar permasalahan klaim kedaulatan semata, tapi bagaimana klaim tersebut diikuti dengan upaya pembinaan wilayah dan masyarakat yang berkesinambungan.

Lepasnya Pulau Sipadan dan Ligitan ke tangan Malaysia melalui keputusan International Court of Justice (ICJ) pada 17 Desember 2002 merupakan sebuah kasus yang cukup menghentak publik Indonesia. Sengketa atas kedua pulau itu sendiri dimulai sejak 1967 ketika dalam sebuah pertemuan untuk membahas hukum laut di antara kedua negara, masing-masing negara memasukkan kedua pulau tersebut ke dalam batas-batas wilayahnya. Menyikapi klaim kedaulatan ini, kedua negara akhirnya bersepakat untuk menetapkan status quo atas kedua pulau tersebut. Dalam dinamikanya, penetapan status quo ini ternyata dimaknai secara berbeda oleh kedua negara. Indonesia memaknai status quo sebagai sebuah kondisi ketika sebuah negara tidak boleh melakukan pendudukan atau aktivitas apapun sampai kedua pulau tersebut memiliki status hukum yang jelas. 
Pemaknaan yang dilakukan oleh Indonesia ini merupakan refleksi atas penghormatan yang dilakukan oleh Indonesia terhadap kaidah hukum internasional yang berlaku. Berbeda dengan Malaysia yang secara frontal melakukan aktivitas bisnis dengan membangun resor pariwisata di kedua pulau yang disengketakan tersebut. Malaysia menerapkan pandangan sepihak yang sangat unilateralis dengan menganggap status quo adalah sebuah kondisi yang mana kedua pulau tersebut tetap berada di bawah kepemilikan Malaysia (Anggraini WS 2014).

Menyikapi kecurangan yang dilakukan oleh Malaysia tersebut, Indonesia akhirnya mampu memaksa Malaysia untuk melakukan perundingan. Perundingan yang dilakukan akhirnya menyepakati sebuah nota kesepahaman pada 22 September 1969 yang isinya mengatur agar baik Indonesia maupun Malaysia tidak boleh menempati, menduduki, atau memanfaatkan kedua pulau tersebut. Pada tataran lebih lanjut, sebagai konsekuensi perbedaan pandangan yang semakin tajam di antara kedua negara, baik Indonesia maupun Malaysia, akhirnya membawa sengketa atas Pulau Sipadan dan Ligitan tersebut ke Mahkamah Internasional (ICJ) untuk diputuskan (Anggraini WS 2014). Mahkamah Internasional sendiri yang dipimpin oleh hakim ketua Gilbert Guillaume dari Prancis pada akhirnya memenangkan Malaysia untuk sengketa ini. Malaysia dinyatakan berhak atas Pulau Sipadan dan Ligitan dikarenakan dianggap telah melakukan kehadiran secara terus menerus di kedua pulau tersebut, melakukan pendudukan secara efektif, serta melaksanakan pengelolaan dan pelestarian alam. Pengakuan atas klaim kedaulatan oleh Malaysia tersebut dituangkan ke dalam Report of International Court of Justice. Dengan adanya pengakuan ini, Malaysia dinyatakan berhak untuk melakukan penarikan garis pangkal sebagai batas wilayah hingga titik terluar Pulau Sipadan dan Pulau Ligitan (Anggraini WS 2014).

Sebelum masuk pada analisis mengenai urgensi pengamanan wilayah dan mekanisme pengamanan wilayah seperti apa yang harus dilakukan, tinjauan secara historis yang sudah dilakukan sebelumnya akan dilengkapi dengan tinjauan studi kasus kontemporer untuk mempertegas urgensi pengamanan wilayah. Studi kasus secara kontemporer yang cukup menarik untuk dilakukan adalah pencermatan terhadap apa yang terjadi di perairan Natuna dalam beberapa tahun terakhir ini. Pemerintah Indonesia cukup disibukkan oleh aksi unilateral Tiongkok melalui kapal-kapal nelayannya yang dikawal oleh coast guard yang kerap melakukan pelanggaran wilayah di perairan Natuna tersebut. Apa yang terjadi bukan hanya sekedar pelanggaran wilayah, tapi juga penangkapan ikan secara ilegal di perairan tersebut. Kedua bentuk pelanggaran berat itulah yang mendorong pemerintah melalui Kementerian Luar Negeri Republik Indonesia (Kemenlu RI) untuk melayangkan protes keras secara resmi kepada Pemerintah Tiongkok pada akhir 2019 yang silam (Anugerah, Mengantisipasi Potensi Konflik di Laut Cina Selatan Dalam Perspektif Pertahanan dan Keamanan Negara 2021).

Telaah terhadap kasus-kasus kontemporer juga menghasilkan temuan bahwa di perbatasan antara Indonesia dan Filipina kerap terjadi kejahatan-kejahatan transnasional, khususnya di Kepulauan Sangihe, Pulau Lipang, Pulau Matutuang, dan Pulau Kawio yang notabene merupakan pulau-pulau terdepan Indonesia. Di Kepulauan Sangihe kerap terjadi pencurian ikan secara ilegal oleh kapal-kapal asing. Pencurian tersebut diperkirakan menyebabkan kerugian besar, yakni hilangnya ikan-ikan seberat 40 ribu ton per tahun. Masyarakat yang hidup di pulau-pulau terdepan yang berbatasan dengan Filipina juga melaporkan bahwa mereka kerap berhadapan dengan perompak bersenjata yang menyerang mereka. Fenomena yang lebih mengkhawatirkan terjadi di pulau-pulau terdepan di Sangihe Talaud, Pulau Miangas, dan Pulau Marore yang juga berbatasan dengan Filipina. Pulau-pulau tersebut dijadikan jalur pasokan logistik dan distribusi senjata dari kelompok-kelompok teroris di Filipina seperti Moro Islamic Liberation Front (MILF) ke kelompok-kelompok teroris di Indonesia, seperti kelompok Santoso atau Abu Wardah di Poso, Sulawesi Tengah. 
Pengamanan wilayah, termasuk pengamanan wilayah pesisir dan pulau-pulau terdepan, sejatinya merupakan tanggung jawab TNI sebagai komponen utama pertahanan negara. Dalam UU TNI, yakni UU No. 34 Tahun 2004, disebutkan bahwa TNI adalah alat negara di bidang pertahanan yang menjalankan fungsinya berdasarkan kebijakan dan keputusan politik negara (Munsharif A. Chalim 2015). Masih merujuk pada UU TNI, sedikitnya ada tiga fungsi yang dijalankan TNI, yakni fungsi penangkal terhadap segala ancaman, gangguan, hambatan, dan tantangan (AGHT) yang datang, baik dari dalam maupun dari luar, fungsi penindak atau punitif terhadap segala AGHT yang muncul, serta fungsi pemulih terhadap kondisi negara yang terganggu akibat AGHT yang muncul tersebut. TNI sendiri sebagai sebuah alat negara terdiri atas tiga matra, yakni matra darat, laut, dan udara. Masing-masing matra memiliki tugas pokok dan fungsi yang berbeda-beda. Dalam konteks pengamanan wilayah pesisir dan pulau-pulau terdepan, maka matra TNI yang memiliki tanggung jawab pengamanan paling besar adalah matra laut yang fokus pada pengamanan zona maritim (Haras 2017).

TNI Angkatan Laut (TNI AL) merupakan bagian integral dari TNI sebagai komponen utama pertahanan negara. Beberapa misi yang diusung oleh TNI AL di antaranya adalah melindungi dan menjaga keutuhan bangsa dan negara, serta menegakkan kedaulatan dan keamanan di laut (Sondakh 2003). Sebagai alat untuk menegakkan kedaulatan negara, ada tiga peran yang dijalankan oleh TNI AL. Pertama, peran militer, yakni melaksanakan pertahanan negara di laut dengan cara menyiapkan kekuatan untuk perang, melakukan penangkalan terhadap segala ancaman di laut, melindungi dan menjaga perbatasan laut Indonesia dengan negara tetangga, serta menjaga stabilitas keamanan di kawasan maritim. Kedua, peran diplomatik. Peran diplomasi yang dimiliki TNI AL sejatinya muncul karena kapasitas mereka sebagai military forces. Peran diplomasi dijalankan oleh TNI AL melalui naval presence atau unjuk kekuatan angkatan laut. Peran diplomasi yang dijalankan oleh TNI AL ini dimaksudkan untuk mendukung diplomasi formal yang dilakukan oleh pemerintah dalam rangka mewujudkan stabilitas dan perdamaian internasional (Antariksa 2014). Sedangkan peran ketiga adalah peran konstabulari, yakni peran polisionil yang dijalankan TNI AL dalam rangka menegakkan hukum nasional di laut. Selain ketiga peran tersebut, TNI AL juga menjalankan peran lainnya dalam kerangka Operasi Militer Selain Perang (OMSP), seperti Search and Rescue (SAR) pada kecelakaan atau bencana di laut (Kumalasari 2006).

Terhadap berbagai persoalan yang muncul di wilayah pesisir dan pulau-pulau terdepan, TNI AL sendiri sudah melakukan berbagai tindakan responsif, baik mitigatif maupun kuratif, sesuai tugas pokok dan fungsinya. TNI AL melakukan patroli laut secara reguler dan pengamanan wilayah perbatasan sesuai dengan postur yang mereka miliki. Tidak hanya itu, TNI AL juga melakukan pemetaan permasalahan secara berkala terkait berbagai ancaman yang kerap muncul di wilayah pesisir dan pulau-pulau terdepan tersebut sebagai bekal untuk perbaikan pola pengamanan wilayah yang akan mereka lakukan ke depan. Sebagai contoh, TNI AL melakukan pemetaan permasalahan perbatasan antara Indonesia dan India. Dalam pemetaan yang dilakukan oleh TNI AL dihasilkan analisis bahwa meskipun telah disepakati perjanjian batas landas kontinen antarkedua negara, akan tetapi persoalan ZEE kedua negara belum terselesaikan. Hal ini berpotensi menimbulkan konflik perbatasan maritim di sekitar wilayah Pulau Andaman dan Pulau Nicobar yang secara tradisional kerap dijadikan nelayan-nelayan Aceh untuk menangkap ikan (Kumalasari 2006).

Secara mendetil, berbagai upaya yang telah dilakukan oleh TNI AL dalam mengamankan wilayah pesisir, wilayah perbatasan, serta pulau-pulau terdepan antara lain sebagai berikut: (a) melakukan survei base point untuk menentukan titik-titik dasar dan garis pangkal kepulauan Indonesia yang telah ditetapkan menjadi PP No. 38 Tahun 2002 tentang Daftar Koordinat Geografis Titik-Titik Garis Pangkal Kepulauan Indonesia, (b) Kapal Republik Indonesia (KRI) di bawah TNI AL diperintahkan untuk melakukan patroli dan mengunjungi pulau-pulau terdepan Indonesia, baik yang berpenduduk maupun yang 
tidak berpenghuni, (c) melaksanakan diplomasi TNI AL melalui peningkatan naval presence (Kehadiran KRI) di wilayah perairan Indonesia yang berbatasan secara langsung dengan negara-negara tetangga, (d) melaksanakan Operasi Bakti Surya Bhaskara Jaya (SBJ) sebagai bentuk kepedulian dan tanggung jawab TNI AL dalam rangka mengakselerasi pembangunan di pulau-pulau terdepan Indonesia yang tidak dapat dijangkau oleh transportasi darat dan udara, (e) merancang program pasar bergerak (mobile market) untuk merangsang kegiatan perekonomian di pulau-pulau terdepan dengan melakukan pergerakan dari pulau ke pulau untuk memobilisasi berbagai kebutuhan pokok masyarakat (Kumalasari 2006). TNI AL tidak hanya mengangkut komoditi pokok tersebut ke pulau-pulau terdepan saja, tapi menjual komoditi tersebut kepada penduduk dengan harga murah, membeli komoditi penduduk di satu pulau untuk dijual ke pulau lainnya sesuai dengan kebutuhan.

Berbagai upaya yang dilakukan oleh TNI AL tersebut merupakan wujud nyata pelaksanaan tanggung jawab mereka sebagai alat pertahanan negara di bidang maritim. Baik wilayah pesisir maupun pulau-pulau terdepan merupakan entitas kemaritiman yang tidak pernah ditinggalkan oleh TNI AL dalam hal pengamanan wilayah. Hanya saja dalam pelaksanaan tugas pokok dan fungsi untuk pengamanan wilayah tersebut, TNI AL menyadari bahwa ada banyak kekurangan secara teknis maupun nonteknis, sehingga mengakibatkan upaya pengamanan yang dilakukan kurang efektif. Disebut kurang efektif karena pelanggaran wilayah kedaulatan kerap terjadi secara berulang meskipun sudah dilakukan penindakan. Kasus pelanggaran kedaulatan di Laut Natuna Utara yang dilakukan oleh kapal-kapal nelayan Tiongkok adalah bukti sahihnya. Secara umum, ada dua permasalahan utama yang dihadapi oleh TNI AL. Pertama, keterbatasan sumber daya manusia, yakni minimnya jumlah personel dan personel terlatih dalam melaksanakan tugas pokok dan fungsi yang diemban. Dalam bahasa lugas, permasalahan terletak pada faktor kualitas dan kuantitas personel. Kedua, keterbatasan sarana dan prasarana (sarpras) dalam pelaksanaan tugas sebagai konsekuensi dari keterbatasan dana yang dimiliki.

Dengan merujuk pada kompleksitas permasalahan yang dihadapi di wilayah pesisir dan pulau-pulau terdepan, serta kompleksitas permasalahan yang dihadapi oleh TNI AL sebagai alat pertahanan negara, dapat disimpulkan bahwa upaya pengamanan wilayah yang dilakukan selama ini belum efektif dan optimal. Dengan demikian yang menjadi persoalan ke depan adalah bagaimana mewujudkan efektivitas dalam pengamanan kedua entitas kemaritiman tersebut. Frasa "efektif" sendiri menjadi kata kunci dalam konteks pengamanan wilayah. Efektif yang dimaksudkan di sini adalah bagaimana mewujudkan pengamanan wilayah yang berdampak secara maksimal terhadap objektif (output atau keluaran) yang ditetapkan. Definisi ini selaras dengan teori efektivitas yang dinyatakan oleh Richard M. Steers, Katz dan Khan, yang menyatakan bahwa efektivitas sangat ditentukan oleh efisiensi dari tindakan yang diambil, serta tercapainya keuntungan yang maksimal (Kahn 1978).

Untuk mewujudkan efektivitas pengamanan wilayah, hal pertama yang harus dilakukan adalah memaknai kembali sistem pertahanan negara Indonesia. Dalam UU No. 3 Tahun 2002 tentang Pertahanan Negara disebutkan bawa sistem pertahanan negara yang dianut oleh Indonesia adalah sistem pertahanan semesta atau Sishanta yang artinya melibatkan seluruh warga negara Indonesia tanpa terkecuali dan seluruh potensi sumber daya nasional yang dimiliki (Samego 2015). Secara implisit, pengaturan sistem pertahanan negara seperti yang diamanatkan dalam UU Hanneg tersebut memberikan pandangan bahwa tugas pertahanan negara tidak bisa semata-mata ditumpukan kepada TNI saja sebagai alat pertahanan negara, tapi juga seluruh warga negara Indonesia. Dalam konteks pengamanan wilayah pesisir dan pulau-pulau terdepan di Indonesia, pengamanan wilayah juga dapat dilakukan oleh masyarakat setempat. Oleh sebab itu, pekerjaan rumah yang harus diselesaikan oleh pemerintah adalah melakukan pembinaan terhadap masyarakat setempat agar dapat menjadi instrumen pertahanan negara yang tangguh di masa yang akan datang. 
Pembinaan terhadap masyarakat di wilayah pesisir dan pulau-pulau terdepan ini dapat dilakukan secara dua arah, yakni model pembinaan secara keras (hard development) maupun pembinaan secara lunak (soft development). Dikarenakan orientasi pada subbagian ini adalah pengamanan wilayah, maka model pembinaan yang dilakukan adalah pembinaan secara keras untuk pengamanan wilayah. Baik pembinaan keras maupun pembinaan lunak, selaras dengan teori pembinaan dan pemberdayaan yang menekankan pada penguatan keterlibatan dan peningkatan kemampuan dalam melaksanakan tugas dan fungsi (Sedarmayanti 2017). Pembinaan masyarakat dalam hal pengamanan wilayah dapat dilakukan oleh pemerintah melalui internalisasi wawasan kebangsaan dan penguatan kesadaran bela negara kepada masyarakat. Dasar dari kebijakan ini adalah pemahaman bahwa semakin meningkat wawasan kebangsaan dan kesadaran bela negara mereka, maka semakin kuat perasaan nasionalisme dan patriotisme mereka kepada negara. Perasaan cinta tanah air dan sense of belonging yang kuat pada negara tersebut yang akan menjadi pendorong bagi mereka untuk menjadi garda depan pertahanan negara.

Pemerintah Indonesia sejatinya sudah memiliki kerangka hukum yang kuat untuk menjadikan masyarakat wilayah pesisir dan pulau-pulau terdepan tersebut sebagai benteng pertahanan terdepan negara dari segala AGHT yang datang, yakni UU No. 23 Tahun 2019 tentang Pengelolaan Sumber Daya Nasional (PSDN) Untuk Pertahanan Negara, serta PP No. 3 Tahun 2021 tentang Peraturan Pelaksanaan UU No. 23 Tahun 2019 tentang PSDN Untuk Pertahanan Negara. Melalui kedua regulasi tersebut, pemerintah dapat melakukan pembinaan secara terpadu kepada masyarakat di wilayah-wilayah tersebut sebagai komponen cadangan untuk mendukung pelaksanaan tugas pokok dan fungsi TNI sebagai alat pertahanan negara. Dengan menjadikan masyarakat di wilayah pesisir dan pulau-pulau terdepan sebagai komponen cadangan, maka keterbatasan yang dimiliki oleh TNI AL dalam hal kualitas dan kuantitas personel dapat dipenuhi. Konversi masyarakat wilayah pesisir dan pulau-pulau terdepan juga dapat menepis anggapan negatif sebagian kalangan yang menyatakan bahwa program komponen cadangan dari Kemenhan RI adalah mobilisasi warga sipil sebagai militer. Proses konversi masyarakat wilayah pesisir dan pulau-pulau terdepan bukan saja kompatibel dengan tantangan yang dihadapi, tapi juga sebuah kebutuhan yang mendesak.

\section{Mewujudkan Efektivitas Pengelolaan Wilayah Pesisir dan Pulau-pulau Terdepan}

Pengelolaan wilayah sejatinya berbasis pendekatan geografis dengan merujuk pada karakteristik wilayah yang akan dikelola. Namun demikian, pengelolaan wilayah juga mencakup aspek demografis dan sosial ekonomi, dikarenakan wilayah tidak akan bisa dikelola atau diberdayakan jika manpower-nya tidak terberdayakan. Secara umum, terdapat lima hal penting yang bisa dijadikan sebagai garis besar pengelolaan oleh pemerintah ke depan. Pertama, keberagaman masyarakat perlu disikapi dengan pendekatan yang sifatnya beragam sesuai dengan karakteristik masyarakat masing-masing. Kedua, pengelolaan yang dilakukan tidak bisa berbasis ekonomi saja, tapi juga harus menyentuh aspek sosial budaya, dikarenakan masyarakat di wilayah tersebut masih memegang erat nilai-nilai tradisionalnya. Ketiga, kemandirian menjadi isu krusial dalam pembinaan dan pemberdayaan masyarakat mengingat faktor dependensi geografis terhadap pulau induk dan entitas lainnya. Keempat, meskipun memiliki keunggulan, wilayah pesisir dan pulaupulau terdepan juga memiliki banyak keterbatasan. Kelima, pembangunan yang dilakukan nantinya harus dilakukan secara cermat, memperhitungkan dampaknya terhadap ekosistem sekitar yang menjadi sumber kehidupan bagi masyarakatnya.

Terkait dengan beragam permasalahan dan kompleksitas yang ada di wilayah pesisir dan pulau-pulau terdepan, Pemerintah Indonesia telah melakukan upaya pengelolaan. Upaya pengelolaan ini tercermin dari regulasi yang sudah diformulasikan, yakni UU No. 1 Tahun 2014 tentang Perubahan Atas UU No. 27 Tahun 2007 tentang Pengelolaan Wilayah Pesisir dan Pulau-Pulau Kecil. Dalam regulasi tersebut dinyatakan 
bahwa pengelolaan wilayah pesisir dan pulau-pulau kecil adalah kegiatan pengkoordinasian perencanaan, pemanfaatan, pengawasan, serta pengendalian yang penyelenggaraannya dilakukan oleh pemerintah dan pemerintah daerah, melibatkan antarsektor, menghubungkan ekosistem darat dan laut, serta memanfaatkan ilmu pengetahuan dan manajemen dalam rangka meningkatkan kesejahteraan masyarakat.

Dalam regulasi tersebut juga disebutkan prioritas pengelolaan wilayah pesisir dan pulau-pulau kecil, yakni ditujukan untuk kepentingan konservasi, pendidikan dan pelatihan, penelitian dan pengembangan, budidaya laut, pariwisata, usaha perikanan dan kelautan serta industri perikanan secara lestari, pertanian organik, peternakan, dan/atau pertahanan keamanan negara. Dalam hal pengelolaan, regulasi mengatur teknis pemanfaatan dan pengelolaan melalui mekanisme izin lokasi dan izin pengelolaan yang diberikan kepada perorangan, korporasi yang didirikan berdasarkan hukum positif di Indonesia, serta koperasi sebagai soko guru perekonomian yang dibentuk oleh masyarakat. Regulasi juga mengatur secara mendetil mengenai tugas dan tanggung jawab pemerintah pusat dan pemerintah daerah.

Pemerintah memiliki kewajiban untuk mendorong tumbuhnya kegiatan usaha masyarakat melalui penguatan kemampuan atau kapasitas, menjamin ketersediaan akses teknologi dan informasi, adanya dukungan modal dan infrastruktur, jaminan pasar untuk menyerap produk masyarakat, serta ketersediaan aset ekonomi produktif lainnya. Keberadaan regulasi yang ada merupakan wujud ikhtiar pemerintah dalam menjalankan kewajibannya dalam rangka memajukan kesejahteraan masyarakat setempat. Namun demikian, pendekatan regulatif membutuhkan realisasi yang dilaksanakan dengan baik, sehingga objektif pembuatan regulasi dapat tercapai secara optimal. Tolok ukur keberhasilan implementasi regulasi tersebut pada hakikatnya sangat sederhana, yakni terpenuhinya kebutuhan dasar masyarakat setempat, wilayah yang melakukan pembangunan secara progresif, wilayah yang stabil secara politik dan keamanan dalam menopang ketahanan nasional, serta masyarakat yang adil, makmur, dan sejahtera. Jika beberapa indikator tersebut tidak tercapai, maka dapat dipastikan ada rumpang nilai (value gap) antara kebijakan dan implementasinya.

Menarik untuk melakukan pencermatan terhadap kondisi perekonomian dan sosial budaya masyarakat pesisir dan pulau-pulau terdepan sebagai evaluasi. Merujuk pada berbagai indikator yang ada, pembangunan wilayah pesisir dan pulau-pulau terdepan yang digalakkan pemerintah sejak 2005 dan diregulasi pada 2007 terlihat sangat lambat dalam implementasinya, tidak berlangsung secara progresif. Lambatnya pembangunan yang dijalankan berdampak terhadap tingginya kemiskinan dan disparitas sosial di wilayah pesisir dan pulau-pulau dibandingkan dengan wilayah-wilayah lainnya. Pada 2017, tingkat kemiskinan di wilayah pesisir dan pulau-pulau terdepan mencapai 35 persen. Angka ini berada di atas angka kemiskinan nasional, yakni di angka 10,64 persen. Data KKP RI pada 2015 menunjukkan bahwa kemiskinan di wilayah pesisir menyumbang 32,14 persen dari total jumlah penduduk miskin nasional (Sabarisman 2017). Ada banyak persoalan teknis yang menjadi kausa utama, seperti armada penangkapan ikan yang masih sangat tradisional, minimnya penguasaan teknologi dalam pemanfaatan sumber daya perairan, serta minimnya ketersediaan infrastruktur. Dalam konteks infrastruktur, salah satu fenomena yang sangat membuat miris adalah bagaimana masyarakat di Pulau Liran Maluku harus menggunakan sarana telekomunikasi dari perusahaan Timor Leste untuk bisa berkomunikasi satu sama lain (Panggabean 2020).

Kondisi masyarakat di wilayah pesisir dan pulau-pulau terdepan menjadi semakin susah tatkala pandemi Covid-19 menghantam Indonesia sejak Maret 2020 lalu hingga kini. Masyarakat mengalami pemerosotan pendapatan, terputusnya supply chain usaha yang dilakukan (perikanan, budidaya, dan lain-lain), serta ketiadaan modal pra-produksi. Dengan situasi dan kondisi masyarakat sedemikian rupa, maka tidak berlebihan apabila upaya pengelolaan wilayah pesisir dan pulau-pulau terdepan yang dilakukan oleh pemerintah selama ini belum berjalan secara tepat guna dan efisien. Respons secara 
regulatif melalui undang-undang, Perpres, serta Keppres terkait, masih lemah dalam tataran implementasinya. Di era otonomi daerah, di mana pemerintah daerah diberikan kewenangan untuk mengatur dan mengelola sendiri wilayah serta sumber daya alam yang dimilikinya, ternyata tidak bisa dikonversi sebagai peluang untuk mewujudkan wilayah yang berdaya tahan, serta masyarakat yang tangguh secara perekonomian.

Eksistensi regulasi dan peluang otonomi daerah tidak mampu membawa masyarakat di wilayah pesisir dan pulau-pulau terdepan untuk lepas landas dari kemiskinan dan keterbelakangan mereka. Dengan situasi dan kondisi seperti ini, pemerintah seyogianya melakukan evaluasi terhadap implementasi kebijakan yang sudah dilakukan, sehingga titik-titik kelemahan yang menyumbang berbagai indikator negatif tersebut dapat segera dibenahi. Berdasarkan tinjauan penulis dengan menelaah indikator-indikator yang ada, serta problematika yang dihadapi masyarakat setempat saat ini, setidaknya ada beberapa kausa atau penyebab.

Pertama, pengelolaan daerah yang tidak berbasis keunggulan komparatif daerah, yang mana keunggulan komparatif sejatinya merupakan modal dasar utama bagi pembangunan di daerah. Pengelolaan daerah yang sudah berbasis keunggulan komparatif, akan tetapi pengelolaan tidak dilakukan dengan memperhatikan prinsip-prinsip eksplorasi dan eksploitasi yang benar, serta menjaga keberlangsungan ekosistem setempat secara keseluruhan. Kedua, otonomi daerah tidak dikonversi oleh pemerintah daerah sebagai peluang untuk membawa daerah dan masyarakatnya lepas landas dari kemiskinan dan keterbelakangan. Otonomi daerah justru dijadikan sebagai sarana untuk memperkaya diri sendiri oleh elit dan kelompok tertentu, sehingga kesejahteraan masyarakat terabaikan. Otonomi daerah menjadi penyebab munculnya eksklusivitas daerah dalam pengelolaan wilayah, yang mana satu daerah terkadang enggan untuk melakukan kerja sama dengan daerah lain yang notabene mampu memenuhi kebutuhan di daerah tersebut.

Ketiga, pemerintah daerah kurang mendorong partisipasi masyarakat dan pemangku kepentingan lainnya dalam pengelolaan wilayah, sehingga kebijakan yang diproduksi bersifat sangat vertikal (elitis) dan sektoral. Padahal dalam perspektif kebijakan publik, tolok ukur keberhasilan sebuah kebijakan berasal dari umpan balik yang diberikan oleh stakeholders lain dan beneficiaries. Keempat, jalur distribusi logistik kerap menjadi kendala utama pembangunan di suatu daerah. Ketiadaan infrastruktur seperti pelabuhan, dermaga, instalasi listrik dan air bersih, serta transportasi laut secara reguler ke daerahdaerah terpencil menjadi penyebabnya. Dukungan infrastruktur yang diberikan oleh pemerintah terkadang parsial sifatnya. Sebagai contoh, bantuan penyediaan kapal-kapal motor, tidak diiringi dengan ketersediaan SPBU/SPBG dan pasokan bahan bakar yang mencukupi dan dipenuhi secara reguler.

Kelima, banyaknya aktivitas kejahatan di laut, seperti perompakan bersenjata atau lanun laut yang membuat masyarakat jadi enggan melaut. Adanya aktivitas illegal fishing oleh negara lain dengan teknologi yang lebih modern dan maju, sehingga nelayan-nelayan tradisional Indonesia kalah bersaing. Masuknya korporasi besar dalam pengelolaan wilayah pesisir dan pulau-pulau terdepan dengan mengantongi izin lokasi dan izin pengelolaan dari pemerintah setempat. Keenam, pemerintah daerah masih bersikap birokratis dalam pengelolaan wilayah, sehingga kerja sama dengan pihak-pihak yang memiliki minat besar untuk memberdayakan wilayah dan masyarakat setempat, seperti LSM lingkungan hidup, peneliti ilmiah, organisasi internasional, serta kelompok masyarakat peduli lainnya menjadi terkendala.

Berbagai problematika dalam pengelolaan wilayah tersebut merupakan tantangan yang harus segera direspons oleh pemerintah secara cepat, tepat, dan akurat. Untuk mewujudkan respons yang sedemikian, tata kelola organisasi dan administrasi menjadi kata kunci. Tata kelola atau manajemen organisasi yang baik selalu mengikuti kaidah Plan, Do, Check, dan Action, yang disingkat PDCA untuk menciptakan kesinambungan pencapaian tujuan. Konsep $P D C A$ ini diaksentuasikan dalam perumusan, implementasi, serta monitoring dan evaluasi kebijakan guna memastikan agar kebijakan yang diambil efektif 
dan efisien. Merujuk pada kompleksitas permasalahan yang dihadapi, pemerintah perlu melakukan pembenahan dalam implementasi kebijakan ke depan. Pembenahan di sini akan komprehensif dan terukur apabila mampu menyentuh tiga pilar utama keberhasilan dalam pengelolaan, yakni (1) pemerintah, (2) masyarakat, serta (3) para pemangku kepentingan lainnya. Ketiga pilar utama tersebut harus mendapatkan pembenahan agar pengelolaan yang dilakukan juga dapat menyentuh objektif utama yang lebih besar, yakni kokohnya kedaulatan NKRI yang menjadi grand purpose dari penelitian ini. Berikut secara rinci pembenahan yang dapat dilakukan oleh pemerintah dalam pengelolaan wilayah pesisir dan pulau-pulau terdepan (expected conditions):

Pemerintah Pusat dan Pemerintah Daerah bersinergi dalam pengelolaan wilayah. Sinergi dapat diwujudkan melalui produksi kebijakan yang saling mendukung dan menguatkan, serta deregulasi kebijakan pengelolaan wilayah yang tumpang tindih. Pemerintah pusat dan pemerintah daerah menjalankan tata kelola pemerintahan yang baik dan bersih untuk memastikan agar segala sumber daya nasional yang diutilisasi dalam pengelolaan wilayah benar-benar efektif dan efisien. Pemerintah melakukan penguatan infrastruktur pendidikan di wilayah pesisir dan pulau-pulau terdepan sebagai investasi jangka panjang dalam membentuk sumber daya manusia yang berkualitas.

Pemerintah daerah harus mengedepankan inklusivitas dalam pengelolaan wilayah pesisir dan pulau-pulau terdepan dengan mengedepankan partisipasi masyarakat yang sebesar-besarnya, kerja sama dengan daerah lain, serta melibatkan partisipasi dari pemangku kepentingan lainnya, terutama pihak swasta nasional peduli; Pemerintah daerah melakukan pengelolaan wilayah pesisir dan pulau-pulau terdepan dengan tidak mengedepankan pendekatan administratif mengingat postur pesisir dan pulau-pulau terdepan yang tidak bisa dilimitasi melalui pendekatan birokratis administratif.

Pemerintah daerah dapat mengedepankan mekanisme pendanaan secara gotong royong untuk mengatasi masalah keterbatasan dana pengelolaan wilayah. Pendanaan gotong royong ini dapat melibatkan partisipasi masyarakat luar daerah yang peduli, termasuk swasta nasional yang hendak berinvestasi; Pemerintah pusat dan pemerintah daerah melakukan pembangunan infrastruktur yang holistik dan terpadu. Ketersediaan infrastruktur tidak bisa bersifat parsial mengingat ada keterhubungan antara infrastruktur satu dengan infrastruktur lainnya.

Masyarakat tidak memposisikan dirinya sebagai objek pembangunan semata, tapi juga subjek pembangunan yang berpartisipasi aktif mendukung dan melaksanakan program-program pemerintah. Masyarakat memanfaatkan dukungan dari pemerintah, baik dalam bentuk bimbingan dan pelatihan, penyediaan infrastruktur, serta modal usaha dengan sebaik-baiknya dengan mengedepankan azas kemanfaatan yang tidak hanya bagi diri sendiri, tapi juga masyarakat dan wilayah secara keseluruhan (Prinsip Nasionalisme). Masyarakat memberikan umpan balik terhadap kebijakan pemerintah yang tidak tepat sasaran; Masyarakat tidak hanya berorientasi pada eksplorasi dan eksploitasi sumber daya alam saja, tapi juga menyeimbangkan dengan mekanisme pemeliharaan yang baik, serta pemanfaatan yang berkesinambungan untuk masa yang akan datang.

Bersinergi dengan pemerintah setempat dan masyarakat dalam melakukan pengelolaan dan pemanfaatan sumber daya alam di wilayah pesisir dan pulau-pulau terdepan. Mendukung pendanaan pengelolaan wilayah melalui mekanisme pendanaan gotong royong yang kerap diinisiasi pemerintah daerah. Melakukan investasi padat karya, sehingga mampu mendorong penyerapan tenaga kerja dalam rangka mengurangi kemiskinan dan pengangguran; Mendukung tata kelola pemerintahan yang baik dan bersih dengan tidak melakukan praktik suap hanya untuk mendapatkan konsesi. 


\section{SIMPULAN DAN REKOMENDASI}

\section{SIMPULAN}

Penelitian ini menghasilkan temuan bahwa pembinaan wilayah yang meliputi pengamanan dan pengelolaan wilayah pesisir dan pulau-pulau terdepan di Indonesia belum dilakukan secara efektif dalam rangka menegakkan kedaulatan nasional. Pengamanan wilayah belum dilakukan secara efektif karena masih banyaknya aktivitas kejahatan transnasional dan pelanggaran kedaulatan nasional di wilayah pesisir dan pulau-pulau terdepan. Selain itu, pengamanan wilayah masih bertumpu pada TNI AL sebagai komponen utama sistem pertahanan negara di matra maritim. Pengelolaan wilayahpun belum dilakukan secara efektif karena masing-masing pemangku kepentingan, yakni pemerintah, masyarakat, serta pemangku kepentingan lainnya, seperti swasta, korporasi, serta masyarakat sipil, belum menjalankan perannya secara optimal. Hal ini berdampak pada belum diberdayakannya wilayah dan masyarakat dengan baik yang tercermin dari masih minimnya sarana dan prasarana, serta tingkat kemiskinan masyarakat yang tinggi di wilayah pesisir dan pulau-pulau terdepan.

Oleh sebab itu, perlu dilakukan pembinaan wilayah secara lebih optimal dengan mengefektifkan pengamanan wilayah melalui pelibatan masyarakat sebagai komponen cadangan dalam sistem pertahanan negara guna mendukung TNI sebagai komponen utama, serta mengefektifkan pengelolaan wilayah dengan memperkuat peran dari masing-masing pemangku kepentingan dan menciptakan sinergitas di antara mereka dalam mendukung terwujudnya masyarakat dan wilayah yang lebih sejahtera perekonomiannya. Dengan pengamanan dan pengelolaan wilayah yang dilakukan secara efektif sebagai bagian dari mekanisme pembinaan wilayah, maka kedaulatan nasional di wilayah pesisir dan pulaupulau terdepan dapat ditegakkan.

\section{REKOMENDASI}

Rekomendasi yang dapat diajukan sebagai tindak lanjut dari penelitian ini antara lain: (a) pengamanan wilayah pesisir dan pulau-pulau terdepan dapat diperkuat melalui pelibatan masyarakat setempat melalui mekanisme komponen cadangan untuk memperbesar kekuatan dan kemampuan TNI AL dalam mempertahankan wilayah maritim Indonesia. Oleh sebab itu, Kemenhan RI dan TNI selaku pemangku kebijakan komponen cadangan perlu mengedepankan perekrutan masyarakat di kedua entitas maritim tersebut; (b) pengelolaan wilayah pesisir dan pulau-pulau terdepan merupakan kerja yang bersifat multidimensi, serta lintas sektoral. Problematika pengelolaan wilayah selama ini disebabkan oleh kurang solidnya para pemangku kepentingan terkait, yakni pemerintah, masyarakat, serta pemangku kepentingan lainnya, seperti swasta, masyarakat sipil, pemerintah daerah lain, serta korporasi nasional. Dibutuhkan soliditas antarpemangku kepentingan agar pola pengelolaan wilayah bersifat holistik, integral, serta komprehensif di masa yang akan datang; (c) mekanisme peningkatan pembinaan wilayah pesisir dan pulau-pulau terdepan melalui pengamanan wilayah dan pengelolaan wilayah merupakan mekanisme yang terkait satu sama lain. Oleh sebab itu, para pemangku kebijakan terkait harus berfikir secara holistik dan integral, tidak terkotak-kotak dalam implementasi masing-masing mekanisme. Penguatan pada aspek pengelolaan misalnya, merupakan fundamen penting bagi wilayah yang lebih aman dan kondusif di masa yang akan datang. 


\section{DAFTAR PUSTAKA}

Agustin Rina Herawati, dkk. 2019. "Pemberdayaan Pulau-Pulau Kecil Terluar Sebagai Garda Terdepan Wilayah NKRI." Journal of Public Policy and Applied Administration.

Anggraini WS, Brigitta. 2014. "Upaya Pemerintah Indonesia Mempertahankan dan Memberdayakan Pulau-Pulau Terluar di Indonesia Pasca Lepasnya Pulau Sipadan dan Ligitan." e-journal Universitas Atma Jaya Yogyakarta: 26.

Antariksa, A. Yani. 2014. "Diplomasi Pertahanan Laut Indonesia Dalam Konteks Pergeseran Geopolitik Kawasan Pada Masa Depan." Jurnal Pertahanan dan Bela Negara Volume 4(2): 1-24.

Anugerah, Boy. 2021. "Mengantisipasi Potensi Konflik di Laut Cina Selatan Dalam Perspektif Pertahanan dan Keamanan Negara." Diakses tanggal 13 September 2021. http://dx.doi.org/10.13140/RG.2.2.24701.08167

Anugerah, Boy. 2021. "Strategi Penguatan Keamanan Maritim Nasional Dalam Rangka Menjaga Kedaulatan NKRI." Diakses tanggal 13 September 2021. http://dx.doi.org/10.13140/RG.2.2.23263.38568

Aryani, Christina. 2021. "Mendorong Lahirnya RUU Keamanan Laut dalam Penguatan Sistem Keamanan Laut." Jurnal Pembangunan Hukum Indonesia Volume 3(2): 155-173.

Haras, Yusrah Muhammad. 2017. "Peran TNI AL Dalam Mendukung Terwujudnya Indonesia Sebagai Poros Maritim Dunia Perspektif Manajemen Pertahanan." Jurnal Program Studi Manajemen Pertahanan: 1-14.

Juwana, Hikmahanto. 2013. "Putusan Mahkamah Internasional Atas Pulau Sipadan dan Ligitan." Jurnal Hukum Internasional Vol 1(1) Okotber 2013: 169-182.

Kahn, Katz and. 1978. The Social Psychology of Organization. New York: John Wiley.

Kumalasari, Francisca Ayu. 2006. "Pengamanan Pulau-Pulau Terluar Indonesia Sebagai Upaya Tegakknya Keutuhan Wilayah NKRI". Surakarta: Fakultas Hukum Universitas Sebelas Maret Surakarta.

Mabes TNI AL. 2018. Keputusan Kasal Nomor Kep 1111/V/2018 tanggal 11 Mei 2018 tentang Doktrin TNI Angkatan Laut Jalesveva Jayamahe. Jakarta: Mabes TNI AL.

Munsharif A. Chalim, Faisal Farhan. 2015. "Peranan dan Kedudukan TNI di dalam RUU Kamnas Ditinjau Dari Perspektif Politik Hukum di Indonesia." Jurnal Pembaharuan Hukum: 102-110.

Panggabean, Kezia Biru Dini. 2020. "Pengelolaan Wilayah Pesisir dan Pulau-Pulau Kecil di Indonesia Berdasarkan Hukum Internasional." Diakses tanggal 9 September 2021.

http://repositori.usu.ac.id/bitstream/handle/123456789/28385/160200454.pdf?seq uence $=1 \&$ is Allowed $=y$

Pushidrosal TNI AL. 2018. Laporan Perkembangan Batas Maritim RI dengan Negara Tetangga Periode Tahun 2018. Jakarta: Pushidrosal.

Sabarisman, Muslim. 2017. "Identifikasi dan Pemberdayaan Masyarakat Miskin Pesisir." Jurnal Sosio Informa Vol.3, No. 03: 216-235.

Samego, Indria. 2015. "Kontekstualisasi Sishanneg: Pemberdayaan Wilayah Pertahanan Dalam Perspektif Perubahan." Jurnal Pertahanan Volume 5(1): 1-13. 
JURNAL Kebijakan Pembangunan Volume 16 Nomor 2 Desember 2021: 237-250

Sedarmayanti. 2017. Manajemen Sumber Daya Manusia, Reformasi Birokrasi, dan Manajemen Pegawai Negeri Sipil. Bandung: Refika Aditama.

Sondakh, Bernard Kent. 2003. "Peran TNI AL Dalam Pengamanan dan Pemberdayaan Pulau Terluar RI." Jurnal Hukum dan Pembangunan: 76-88. 